\title{
A New Record of Pandalid Shrimp Procletes levicarina (Crustacea: Decapoda: Caridea) from Korean Waters
}

\author{
Jung Nyun Kim*, Jung Hwa Choi, Taeg Yun Oh, Kwang Ho Choi and Dong Woo Lee \\ Fisheries Resources Management Division, National Fisheries Research and Development Institute, Busan 619-705, Korea
}

\begin{abstract}
The pandalid shrimp Procletes levicarina (Bate, 1888) was newly collected from the western and southern waters of Jeju Island, Korea. This species is the only known member of the genus Procletes which belongs to the family Pandalidae. Morphological description and illustration with a color photograph of the species are given. With the addition of P. levicarina, the family Pandalidae in Korean waters consists of 10 species belonging to 5 genera.
\end{abstract}

Key words: Procletes levicarina, Pandalidae, Decapoda, South Sea of Korea, New record

\section{Introduction}

Korean pandalid shrimps have been known to be composed 9 species in 4 genera (Kim and Kim, 1997; Cha et al., 2001). From the western and southern waters of Jeju Island, Korea, a pandalid species, Procletes levicarina (Bate, 1888), was newly collected by bottom otter trawl from depths of 83-97 m. This represents a new member of the Korean carcinological fauna. Morphological description and illustration with a color photograph of the species are given.

Specimens examined have been deposited in the Fisheries Resource Management Division, National Fisheries Research and Development Institute (NFRDI). Postorbital carapace length (CL) was used as the standard length of the specimens for measurements, and the terminology primarily followed Chace (1985).

\section{Systematic Accounts}

Family Pandalidae

Genus Procletes Bate, 1888

(New Korean name: Gasi-dowha-saewoo-sok)

Procletes levicarina (Bate, 1888)
(New Korean name: Gasi-dowha-saewoo) (Figs. 1, 2)

Dorodotes levicarina Bate, 1888: 680 (type locality: Arafura Sea west of Torres Strait; $51 \mathrm{~m}$ ).

Heterocarpus (Heterocarpoides) levicarina - De Man, 1920: 110, 178, pl. 15, fig. 44-44f.

Heterocarpoides levicarina - Calman, 1939: 207; Liu, 1963: 231; Chace, 1985: 16, figs. 11, 12.

Heterocarpus (Heterocapoides [sic]) glabrus Zarenkov, 1971: 193, fig. 4 (16-27) (type locality: South China Sea; 75 m).

Heterocarpus (Procletes) levicarina - Menon, 1972: 382-390. Procletes levicarina - Holthuis, 1993, 278, fig. 277; Miyake, 1998: 187 (list); Li and Komai, 2003: 271.

Material examined. Western water of Jeju Island, $33^{\circ} 0.1^{\prime} \mathrm{N}$ $125^{\circ} 06.2^{\prime} \mathrm{E}, 83 \mathrm{~m}$, bottom otter trawl, March 14, 2002, 1 male (CL $12.0 \mathrm{~mm}$ ), 1 female (CL $13.7 \mathrm{~mm}$ ), NFRDI-CR 20111015 1; Southern water of Jeju Island, $32^{\circ} 21.1^{\prime} \mathrm{N} 126^{\circ} 3.7^{\prime} \mathrm{E}, 97 \mathrm{~m}$, bottom otter trawl, March 15, 2002, 2 males (CL 14.2, 15.0 mm), 2 females (CL 14.8, 16.8 mm) NFRDI-CR 20111015-2.

Description. Rostrum (Fig. 1A) longer than carapace length, overreaching antennal scale, somewhat upward distally; dorsal margin armed with 11-14 teeth, including 4 or 5
Open Access http://dx.doi.org/10.5657/FAS.2011.0399

This is an Open Access article distributed under the terms of the Creative Commons Attribution Non-Commercial License (http://creativecommons. org/licenses/by-nc/3.0/) which permits unrestricted non-commercial use, distribution, and reproduction in any medium, provided the original work is properly cited. pISSN: 2234-1749 eISSN: 2234-1757
Received 18 October 2011; $\quad$ Revised 31 October 2011; Accepted 7 November 2011

*Corresponding Author

E-mail: crangonk@nfrdi.go.kr 


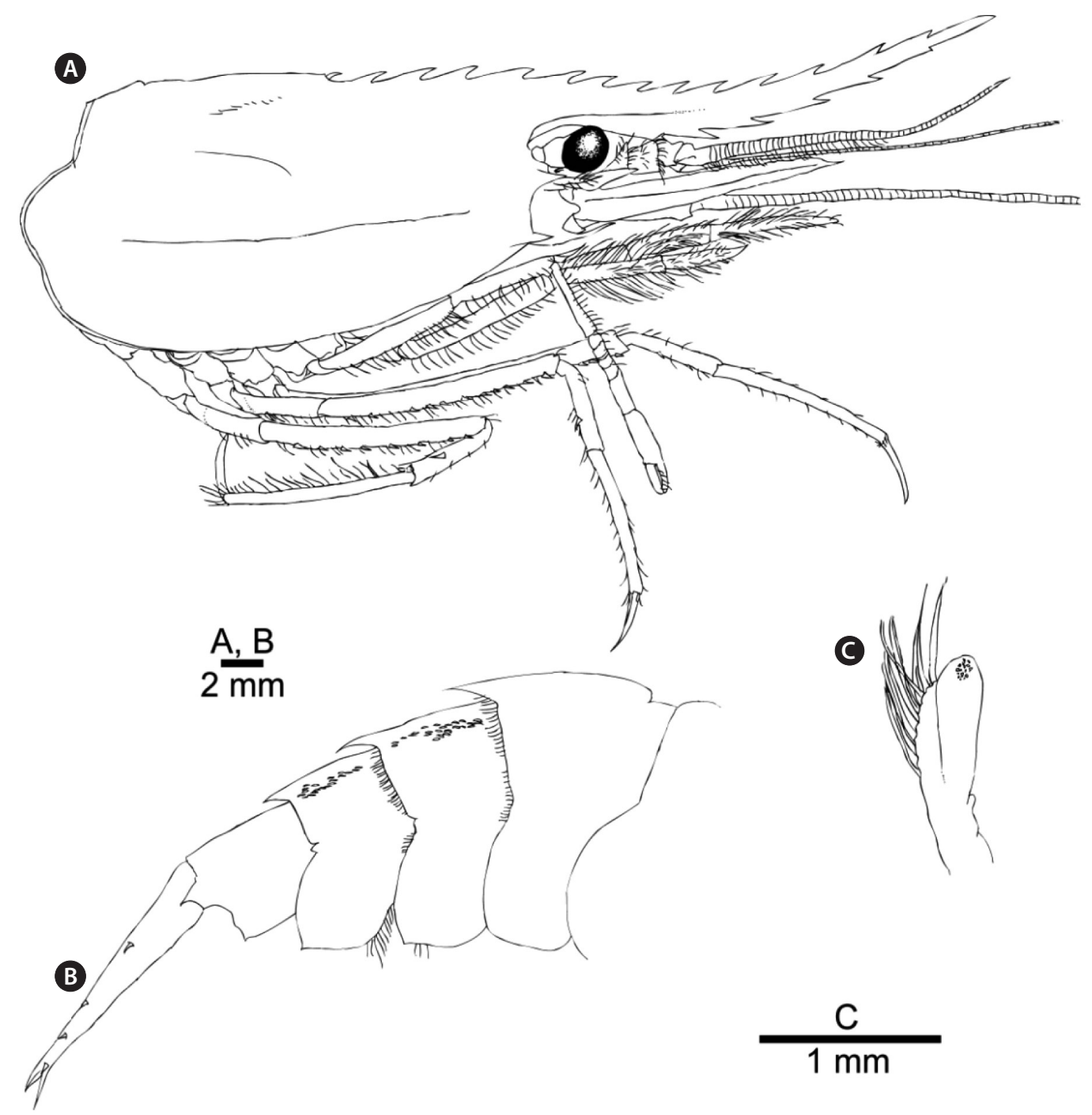

Fig. 1. Procletes levicarina (Bate, 1888) from the western water of Jeju Island. (A, B) Female (postorbital carapace length $13.7 \mathrm{~mm}$ ), (C) male (postorbital carapace length $12.0 \mathrm{~mm}$ ). (A) Carapace and cephalothoracic appendages, lateral. (B) Third to sixth abdominal somites and telson, lateral. (C) Left appendix masculina and appendix interna, mesial.

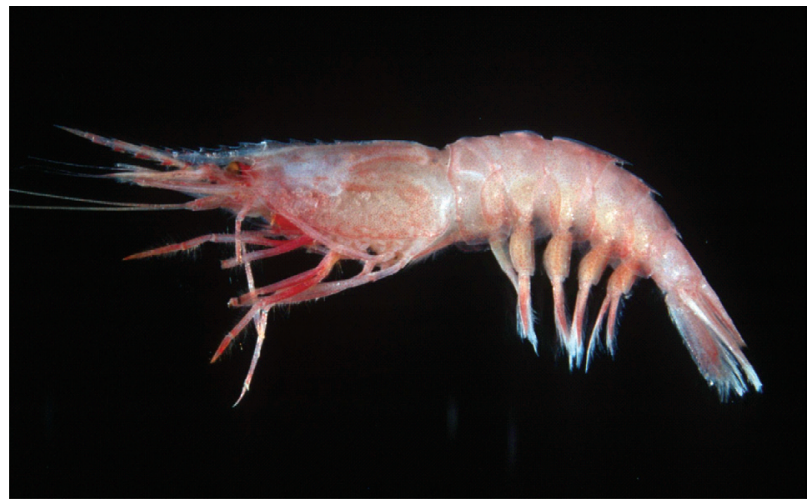

Fig. 2. Procletes levicarina (Bate, 1888), female (postorbital carapace length $14.8 \mathrm{~mm}$ ) from the southern water of Jeju Island. teeth on carapace posterior to level of orbital margin, posteriormost tooth with distinct basal suture; ventral margin armed with 5-7 teeth. Carapace (Fig. 1A) dorsally carinate nearly to posterior margin; posterior end of dorsomedian carina with small papilla; strong antennal and branchiostegal spines present; lateral carinae not sharp but distinct. Abdomen (Fig. 1B) with dorsomedian carina on all somites; third to fifth somites each with strong posteromedian tooth; pleura of fourth to sixth somites with small tooth posteroventrally; tergum of fourth and fifth somites with numerous tegumental scales. Telson (Fig. 1B) armed with 4 pairs of small dorsolateral spines, posterior pair superimposed above bases of lateral pair of posterior spines, posterior margin acutely triangular, with pair of long, stout, lateral spines and median pair of contiguous spines concealed beneath triangular margin. Eye (Fig. 1A) 
with papilla on ventromedian surface of eyestalk proximal to cornea. Antennular peduncle (Fig. 1A) falling short of half of antennal scale; stylocerite acute, overreaching basal segment. Antennal scale (Fig. 1A) with distolateral tooth overreaching distal margin of blade. Third maxilliped with epipod and exopod. Pereopods (Fig. 1A) with epipods on first to fourth pairs; second pair subequal and similar, carpus composed of 6 or 7 articles; third pair with dactylus about $2 / 5$ as long as propodus; carpus unarmed or armed with 1 or 2 small spines, merus with 11-16 small spines, ischium with 1 small spine; fourth pair more slender than third pair, carpus with 1 small spine, merus with 9-11 small spines, ischium with 1 or 2 small spines; fifth pair more slender than fourth pair, carpus with 1 small spine, merus with 7 or 8 small spines, ischium without spine. Appendix interna on second pleopod (Fig. 1C) broad distally; appendix masculina armed with more than 20 long spines on anteromesial and distal margins.

Coloration. Milky brown or light brown in base color scattered with red or pink small spots; rostrum somewhat transparent; thoracic appendages red (Fig. 2).

Distribution. Red Sea to Indonesia, South China Sea, Philippines and Japan; 14-393 m (Li and Komai, 2003) and Korea (present study). Western and southern waters of Jeju Island from 83 to $97 \mathrm{~m}$ in this study.

Size. Maximum CL $18.1 \mathrm{~mm}$ in female ( $\mathrm{Li}$ and Komai, 2003).

Remarks. The genus Procletes includes only one species, $P$. levicarina. The genus is distinguished from the other Pandalidae genera by the following combination of characteristics: (1) the postrostral carina on the carapace extends nearly to the posterior margin; (2) longitudinal carinae on the lateral surface of the carapace are usually present; (3) the second pereopod is subequal and similar; and (4) the carpus of the second pereopod is composed of no more than 6 articles. The present specimens generally coincided with previous descriptions of P. levicarina (cf. Bate, 1888; De Man, 1920; Chace, 1985; Li and Komai, 2003), except for the number of carpal articles of the second pereopod. The carpus of the second pereopod in the present specimens consisted of 6 articles, except for one female specimen with 7 articles (CL $16.8 \mathrm{~mm}$, NFRDI-CR 20111015-2). The number of articles of the carpus of the second pereopod has been known to vary between 5 and 6 (Chace, 1985; Li and Komai, 2003). Thus, including the present results, the article number of the carpus of the second pereopod varies between 5 and 7 within this species. Also, Chace (1985) and Li and Komai (2003) reported that the development of the lateral carinae on the carapace is variable from weak to rather distinct. The development of the median carina on the first abdominal somite is also variable from conspicuous to discernible as a trace or absent. However, these characteristics did not vary in the Korean specimens; the lateral carinae on the carapace were distinct and the median carina on the first abdominal somite was conspicuous.

\section{Acknowledgments}

This work was funded by the National Fisheries Research and Development Institute (RP-2011-FR-046).

\section{References}

Bate CS. 1888. Report on the Crustacea Macrura collected by H.M.S. Challenger during the years 1873-76. Rep Sci Results Voyag H.M.S. Chall 1873-76, Zool 24, 1-942.

Calman WT. 1939. Crustacea: Caridea. Sci Rep John Murray Exped 6, $183-224$

Cha HK, Lee JU, Park CS, Baik CI, Hong SY, Park JH, Lee DW, Choi YM, Hwang K, Kim ZG, Choi KH, Sohn H, Sohn MH, Kim DH and Choi JH. 2001. Shrimps of the Korean Waters. National Fisheries Research and Development Institute, Busan, KR.

Chace FA Jr. 1985. The caridean shrimps (Crustacea: Decapoda) of the Albatross Philippine Expedition, 1907-1910, Part 3: Families Thalassocarididae and Pandalidae. Smithsonian Contrib Zool 411, 1-143.

De Man JG. 1920. The Decapoda of the Siboga Expedition, IV: Families Pasiphaeidae, Stylodactylidae, Hoplophoridae, Nematocarcinidae, Thalassocaridae, Pandalidae, Psalidopodidae, Gnathophylidae, Processidae, Glyphocrangonidae and Crangonidae. Siboga-Expeditie 39a3, 1-318.

Holthuis LB. 1993. The recent genera of the caridean and stenopodidean shrimps (Crustacea, Decapoda) with an appendix on the order Amphionidacea. Nationaal Natuurhistorisch Museum, Leiden.

Kim HS and Kim W. 1997. Order Decapoda. In: List of Animals in Korea (Excluding Insects). The Korean Society of Systematic Zoology, Seoul, KR, pp. 212-223.

Li X and Komai T. 2003. Pandaloid shrimps from the northern South China Sea, with description of a new species of Plesionika (Crustacea: Decapoda: Caridea). Raffles Bull Zool 51, 257-275.

Liu JY. 1963. Zoogeographical studies on the macrurous crustacean fauna of the Yellow Sea and the East China Sea. Oceanol Limnol Sin 5, 230-244.

Menon PG. 1972. Decapod Crustacea from the International Indian Ocean Expedition: the larval development of Heterocarpus (Caridea). J Zool (Lond) 167, 371-397.

Miyake S. 1998. Japanese crustacean decapods and stomatopods in color. Vol. 1. Macrura, Anomura and Stomatopoda. 3rd ed. Hoikusha, Oksaka, JP.

Zarenkov NA. 1971. Contribution to the study of the species and of the geographic distributuion of the marine shrimps belonging to the families Hippolytidae and Pandalidae (Crustacea Decapoda). Complexnie Issled Prirodi Okeana Mosk Univ 2, 176-195. 